\title{
Impacts of chemical degradation on the global budget of atmospheric levoglucosan and its use as a biomass burning tracer
}

Yumin $\mathrm{Li}^{1,2}$, Tzung-May Fu ${ }^{1,3, *}$, Jian Zhen $Y u^{2,4, *}$, Xu Feng ${ }^{1,5}$, Lijuan Zhang ${ }^{1,5}$, Jing Chen ${ }^{6,7}$, Boreddy, Suresh Kumar Reddy,8, Kimitaka Kawamura ${ }^{6,9}$, Pingqing Fu $^{10}$, Xin Yang ${ }^{1,3}$, Lei Zhu ${ }^{1,3}$, Zhenzhong Zeng ${ }^{1,3}$

${ }^{1}$ School of Environmental Sciences and Engineering, Southern University of Science and Technology, Shenzhen, Guangdong Province, 518055,China

${ }^{2}$ Division of Environment and Sustainability, Hong Kong University of Science and Technology, Hong Kong, 999077, China

${ }^{3}$ Shenzhen Institute of Sustainable Development, Southern University of Science and Technology, Shenzhen, Guangdong Province, 518055, China

${ }^{4}$ Department of Chemistry, Hong Kong University of Science and Technology, Hong Kong, 999077, China

${ }^{5}$ Department of Atmospheric and Oceanic Sciences, School of Physics, Peking University, Beijing, 100871,China

${ }^{6}$ Institute of Low Temperature Science, Hokkaido University, Sapporo 060-0819, Japan

${ }^{7}$ School of Environmental Science and Engineering, Tianjin University, Tianjin, 300072, China

${ }^{8}$ Space Physics Laboratory, Vikram Sarabhai Space Centre, Indian Space Research Organization (ISRO), Thiruvananthapuram 695022, India

${ }^{9}$ Chubu Institute for Advanced Studies, Chubu University, Kasugai 487-8501, Japan

${ }^{10}$ School of Earth System Science, Tianjin University, Tianjin, 300072, China 
28 List of Texts, Tables, and Figures

31 Pg S3-4: Text S1. Details of the GEOS-Chem model and the emission inventories used in this

32 study.

33 Pg S5-6: Text S2. Sensitivity simulation on degradation rates of levoglucosan

34 Pg S7-11: Table S1. Observed and simulated concentrations of particulate levoglucosan, OC and $35 \mathrm{~K}^{+}$concentration used in this study.

36 Pg S12: Figure S1. Simulated gas-phase levoglucosan concentration.

37 Pg S13-14: Figure S2. Scatter plots of the observed and simulated particulate levoglucosan 38 concentrations.

39 Pg S15: Figure S3. (a) The difference between [L] and [ $\left.\mathrm{L}_{\mathrm{NOCHEM}}\right]$, and the simulated global

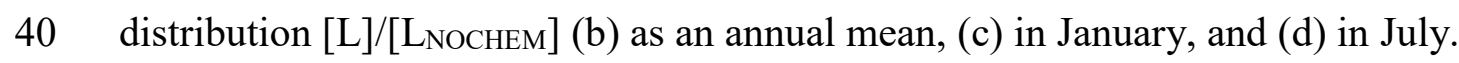

41 Pg S16: Figure S4. Scatterplots of (a) the simulated $[\mathrm{L}] /\left[\mathrm{L}_{\mathrm{NOCHEM}}\right]$ ratio $(\equiv x)$ versus the simulated $42\left[\mathrm{SO}_{2}\right] /\left(\left[\mathrm{SO}_{2}\right]+\left[\mathrm{SO}_{4}{ }^{2-}\right]\right)$ ratio, and (b) the simulated $[\mathrm{L}] /\left[\mathrm{L}_{\text {NOCHEM }}\right]$ ratio versus the simulated $43[\mathrm{~L}] /\left[\mathrm{K}^{+}\right]$ratio, where $\left[\mathrm{K}^{+}\right]$is the concentration of total $\mathrm{K}^{+}$.

44 Pg S17: Figure S5. Scatterplots of the simulated $[\mathrm{L}] /\left[\mathrm{L}_{\text {NOCHEM }}\right]$ ratio ( $\equiv x$ ) (a) versus the simulated $45\left[\mathrm{NO}_{\mathrm{x}}\right] /\left[\mathrm{NO}_{\mathrm{y}}\right]$ ratio and $(\mathrm{b})$ versus the simulated $[\mathrm{L}] /\left[\mathrm{K}^{+}{ }_{\mathrm{BB}}\right]$ ratio, where $\left[\mathrm{K}^{+}{ }_{\mathrm{BB}}\right]$ is the concentration 46 of $\mathrm{K}^{+}$emitted from biomass burning.

47 Pg S18-22: References. 
S1. Details of the GEOS-Chem model and the emission inventories used in this study

GEOS-Chem was driven by the GEOS-FP assimilated meteorological dataset

51 (https://gmao.gsfc.nasa.gov/GMAO_products/) from the Goddard Earth Observing System of the

52 NASA Global Modeling Assimilation Office. GEOS-FP has a native horizontal resolution of

$53 \quad 0.3125^{\circ}$ longitude $\times 0.25^{\circ}$ latitude, with 72 vertical layers extending from the surface to $0.01 \mathrm{hPa}$.

54 To drive our GEOS-Chem simulation, we interpolated the meteorological fields to $5^{\circ}$ longitude $\times$

$554^{\circ}$ latitude. Meteorological fields were updated in GEOS-Chem every 3 hours (every hour for

56 surface fields).

57 GEOS-Chem included a comprehensive $\mathrm{HO}_{\mathrm{x}}-\mathrm{NO}_{\mathrm{x}}-\mathrm{VOC}$-ozone-halogen-aerosol mechanism for

58 tropospheric chemistry. ${ }^{1-3}$ Aerosols in the standard GEOS-Chem model included dust, sea salt,

59 elemental carbon aerosol, primary OC, secondary inorganic aerosol (sulfate, nitrate, ammonium),

60 and secondary organic aerosol. ${ }^{4-7}$ Thermodynamics of secondary inorganic aerosol were computed

61 with the ISORROPIA module (version 2.2). ${ }^{1,8,9}$ Freshly emitted OC were assumed to be $50 \%$

62 hydrophobic and $50 \%$ hydrophilic, with a conversion timescale from hydrophobic to hydrophilic

63 of 1.2 days. ${ }^{4}$ Secondary organic aerosols were simulated using prescribed, irreversible yields from

64 the anthropogenic and biogenic precursor. ${ }^{7}$ The organic aerosol to organic carbon mass ratios were

65 assumed to be 1.4 for primary organic aerosol and 2.1 for secondary organic aerosol. ${ }^{10}$ The

66 transport of atmospheric constituents was simulated using the TPCORE advection algorithm. ${ }^{11}$

67 Dry deposition of aerosols and gases was simulated by the resistance-in-series scheme. ${ }^{12,13}$ Wet

68 deposition of aerosols and gases was calculated as described in Liu et al. ${ }^{14}$ and Amos et al. ${ }^{15}$. The

69 scavenging efficiency for fine, hydrophilic particulates was assumed to be unity. 
70 Monthly anthropogenic emissions of OC (except biofuel emissions) and other pollutants were

71 from the Community Emissions Data System ${ }^{16}$ (CEDS, native resolution $0.3125^{\circ}$ longitude $\times 0.25^{\circ}$

72 latitude, https://esgf-node.llnl.gov/search/input4mips/) by default. However, we superseded CEDS

73 over the U.S. by the National Emissions Inventory 2011 (NEI11, native resolution $0.1^{\circ}$,

$74 \mathrm{http} / /$ ww.epa.gov/air-emissions-inventories), over Canada by Air Pollutants Emissions Inventory

75 (APEI, native resolution $0.1^{\circ}$, http://ec.gc.ca/inrp-npri/donnees-data/ap), over East Asia by the

76 Multiresolution Emission Inventory (MIX, native resolution $\left.0.25^{\circ}\right),{ }^{17}$ over Africa by the Diffuse

77 and Inefficient Combustion Emissions in Africa inventory (DICE-Africa) (native resolution

$\left.780.1^{\circ}\right),{ }^{18}$ because these regional inventories incorporated better information. Biomass burning

79 emissions (except for levoglucosan, $\mathrm{OC}$, and $\mathrm{K}^{+}$) were from the Global Fire Emissions Database ${ }^{19}$

80 (GFEDv4.1s, native resolution $0.25^{\circ}$, http://www.globalfiredata.org). Biogenic volatile organic

81 compound emissions were calculated online in GEOS-Chem using the MEGAN algorithm

$82(\mathrm{v} 2.1) .^{20}$ 
A major source of uncertainty in our simulated concentrations and lifetimes of atmospheric

85 levoglucosan is associated with the rates of levoglucosan's chemical degradation. We conduct

86 sensitivity simulations to evaluate the impacts of faster aqueous and heterogeneous oxidations on

87 the simulated levoglucosan concentrations.

88 As discussed in section 3.3, aqueous oxidation is the dominant removal process of levoglucosan

89 from the atmosphere. The reported rate constants for the aqueous oxidation of levoglucosan against

$90 \mathrm{OH}$ and $\mathrm{NO}_{3}$ were temperature-dependent, with relative small reported ranges of uncertainty (eqs

915 and 6 in the main text). ${ }^{21}$ We conduct a sensitivity simulation using the upper limits $\left(r_{\mathrm{OH}}(\mathrm{T})=\right.$

$92[\mathrm{~L}]_{\mathrm{aq}} \cdot[\mathrm{OH}]_{\mathrm{aq}} \cdot(8.7+0.4) \times 10^{10} \exp \left(\frac{-1083}{T}\right) \quad$ and $\quad r_{\mathrm{NO}_{3}}(\mathrm{~T})=[\mathrm{L}]_{\mathrm{aq}} \cdot\left[\mathrm{NO}_{3}\right]_{\mathrm{aq}} \cdot(2.3+0.1) \times 10^{10}$

$\left.93 \exp \left(\frac{-2141}{T}\right)\right)$ of the reported rate constants to investigate the effects of faster aqueous-phase

94 oxidation on the simulated concentrations and global atmospheric lifetimes of atmospheric

95 levoglucosan.

96 Laboratory-reported heterogeneous oxidation rates of levoglucosan vary widely, particularly

97 for $\mathrm{OH}$. The reported values of the $\mathrm{OH}$ uptake coefficient $\left(\gamma_{\mathrm{OH}}\right)$ ranged from 0.08 to $1 .^{22-25}$ Some

98 laboratory studies reported measured second-order rate constants $k_{2}$ against $\mathrm{OH}$, which ranged

99 from $3.2 \times 10^{-14}$ to $1.25 \times 10^{-11}\left(\mathrm{~cm}^{3}\right.$ molecule $\left.{ }^{-1} \mathrm{~s}^{-1}\right){ }^{24,26}$ Using the equation $k_{2}=\frac{3 \gamma \omega M}{2 D \rho N_{A}}$ (where $D$

100 is the surface area-weighted mean particle diameter, $\rho$ is the density of the organic compound, $N_{A}$

101 is the Avogadro's number, and $M$ is the molecular weight of the organic compound), these reported

$102 k_{2}$ values translate to effective $\gamma_{\mathrm{OH}}$ values of 0.03 to $27 .{ }^{22,24-26} \mathrm{For} \mathrm{O}_{3}, \mathrm{NO}_{3}$ and $\mathrm{N}_{2} \mathrm{O}_{5}$, the reported

103 values of $\gamma$ ranged $(0.001$ to 0.025$) \times 10^{-3},(0.35$ to 2.23$) \times 10^{-3}$, and $(0.01$ to 0.064$) \times 10^{-3}$,

104 respectively. ${ }^{27}$ Several studies also reported temperature or RH dependencies of $\gamma^{23,24,26}$ but the 
105 variability associated with temperature or RH is much smaller than the uncertainty associated with

106 the wide reported range of $\gamma \cdot{ }^{22-26}$ We also conduct a sensitivity simulation using the highest-

107 reported values of $\gamma$ for each oxidant $\left(\gamma_{\mathrm{OH}}=27, \gamma_{\mathrm{O} 3}=2.5 \times 10^{-5}, \gamma_{\mathrm{NO} 3}=2.3 \times 10^{-3}, \gamma_{\mathrm{N} 2 \mathrm{O} 5}=6.4 \times 10^{-}\right.$ $\left.1088^{5}\right)$

109 Figure S2c and S2d show the results from the sensitivity simulations. Faster aqueous-phase 110 oxidation has very little impact on the simulated levoglucosan concentration at all sites, due to the 111 small reported range of the aqueous reaction rates. Using the high-end aqueous reaction rates, the 112 simulated global budget of atmospheric levoglucosan is $18.6 \mathrm{Gg}$ with a lifetime of 1.78 days, which 113 are very similar to our simulation with standard degradation rates (section 3.3). Our model does 114 not include the oxidation of levoglucosan in aqueous aerosols due to the aerosol liquid water being 115 much smaller than the cloud water content under typical conditions. However, our sensitivity test 116 here shows that additional aqueous oxidation on aerosols should have small impact on the global 117 budget of levoglucosan.

118 On the other hand, using much faster heterogeneous uptake coefficients (particularly $\gamma_{\mathrm{OH}}=27$ ) 119 led to significant decreases of the simulated particulate levoglucosan concentrations at remote sites 120 by a factor of 2 . This result leads to a slightly sharper contrast of the simulated particulate 121 levoglucosan concentrations between near-source and remote sites, which is not supported by the 122 available measurements (Figure S2d). Using the high-end heterogeneous uptake coefficients, the 123 simulated global budget of atmospheric levoglucosan is $15.1 \mathrm{Gg}$ with a lifetime of 1.45 days. These 124 numbers are not significantly different from our simulation using standard uptake coefficients, 125 because heterogeneous uptake is a relatively minor sink of atmospheric levoglucosan. 
127 Table S1. Observed and simulated concentrations of particulate levoglucosan, $\mathrm{OC}$ and $\mathrm{K}^{+}$

128 concentration used in this study: observed levoglucosan concentration (LoBs), simulated

129 levoglucosan concentration with (L) and without atmospheric degradation (L NOCHEM$_{\text {) }}$, observed

$130 \mathrm{OC}$ concentration (OCOBS), simulated $\mathrm{OC}$ concentration $(\mathrm{OC})$, observed $\mathrm{K}^{+}$concentration $\left(\mathrm{K}^{+} \mathrm{OBS}\right)$,

131 and simulated $\mathrm{K}^{+}$concentration $\left(\mathrm{K}^{+}\right)$. Some of the $\mathrm{K}^{+}$measurements were made in the same area

132 as the levoglucosan measurements but not from the same campaign.

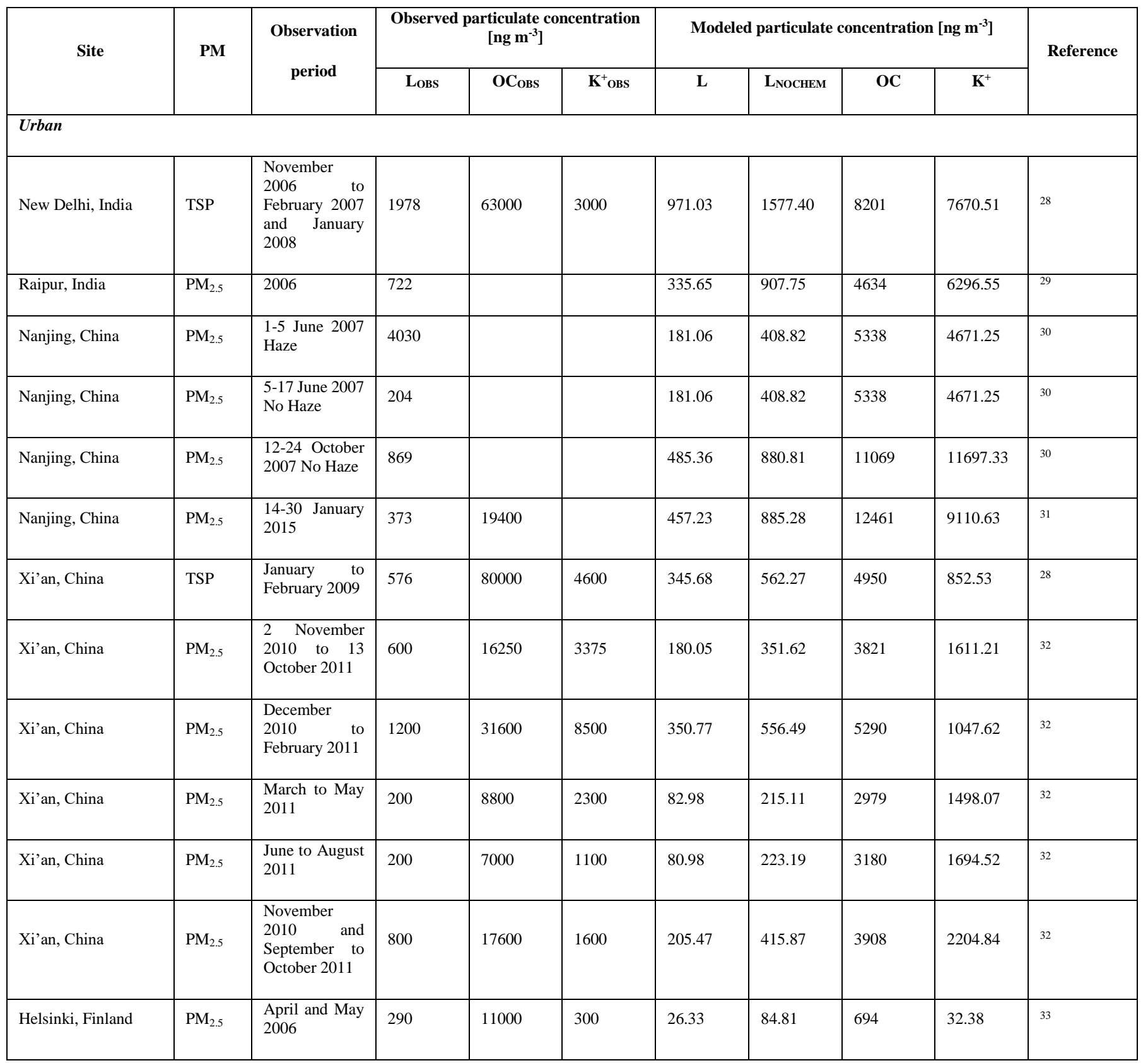




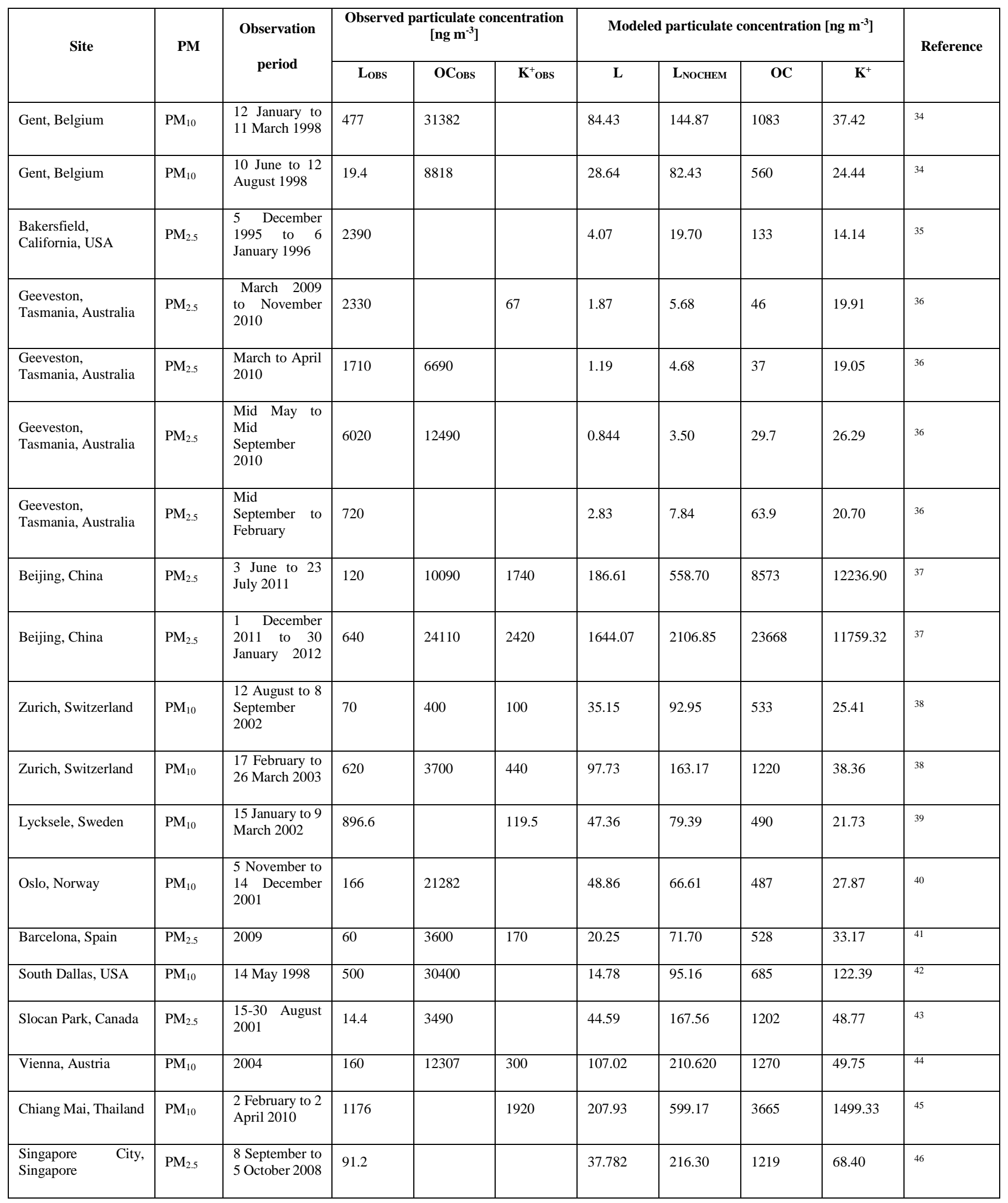




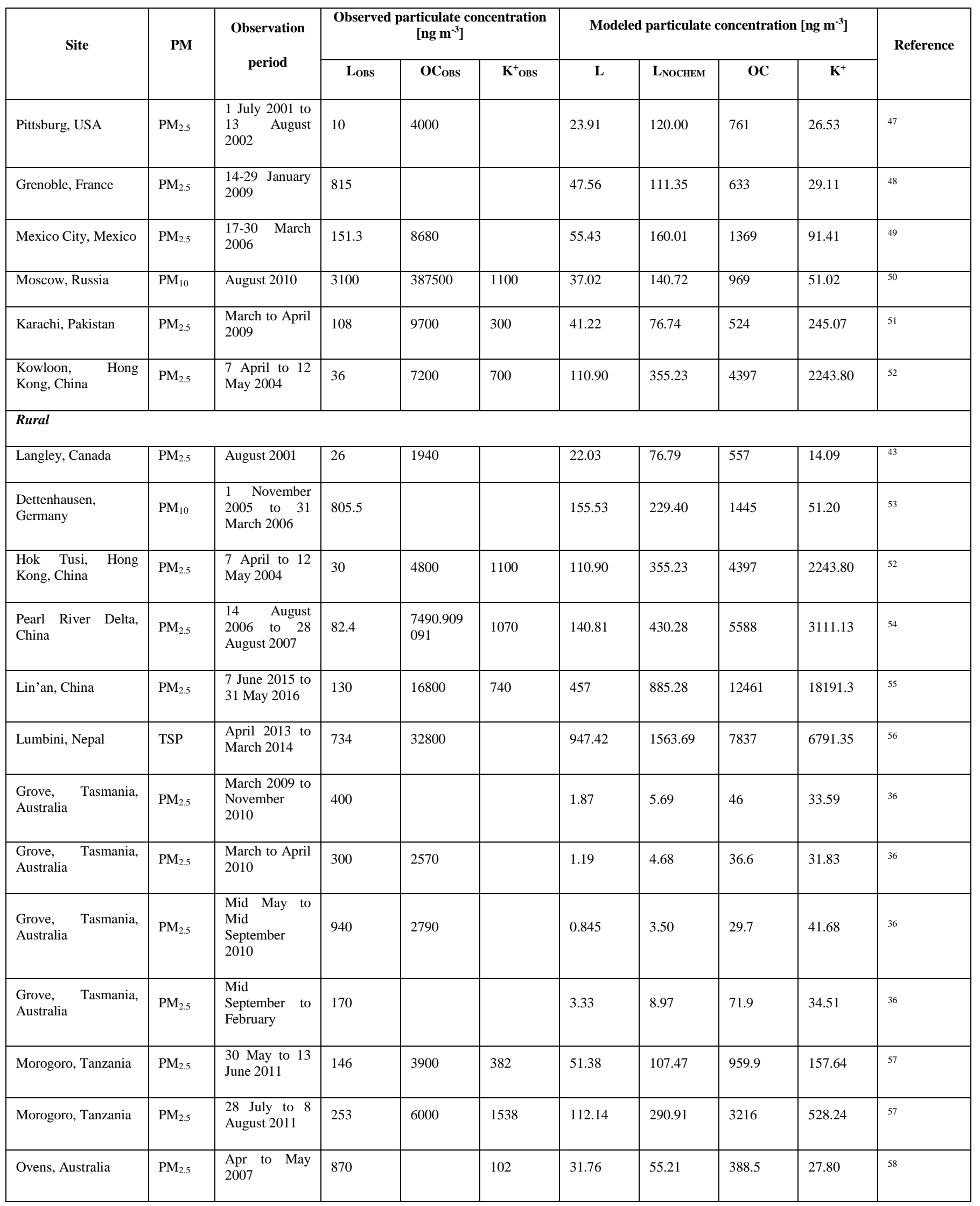




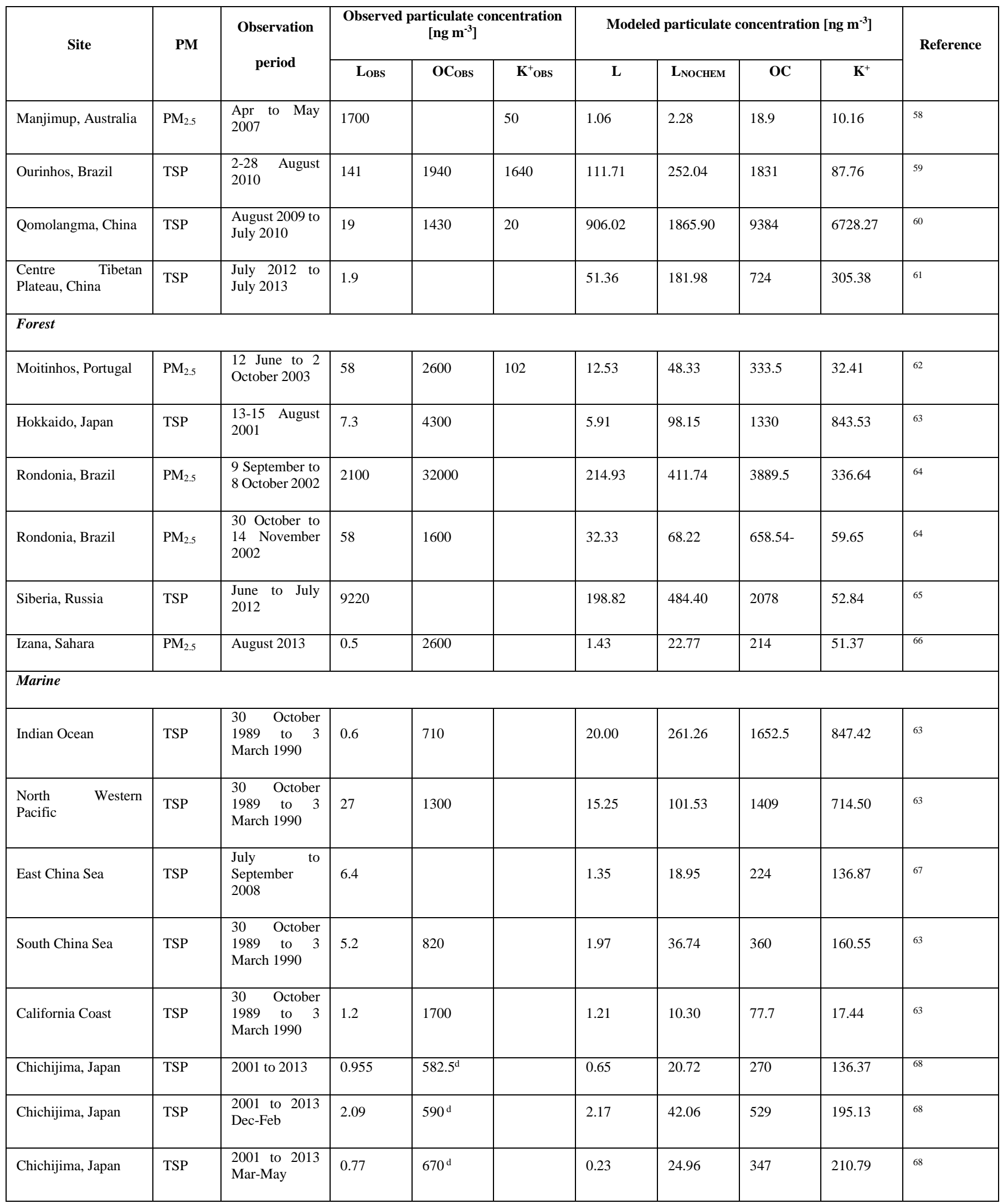




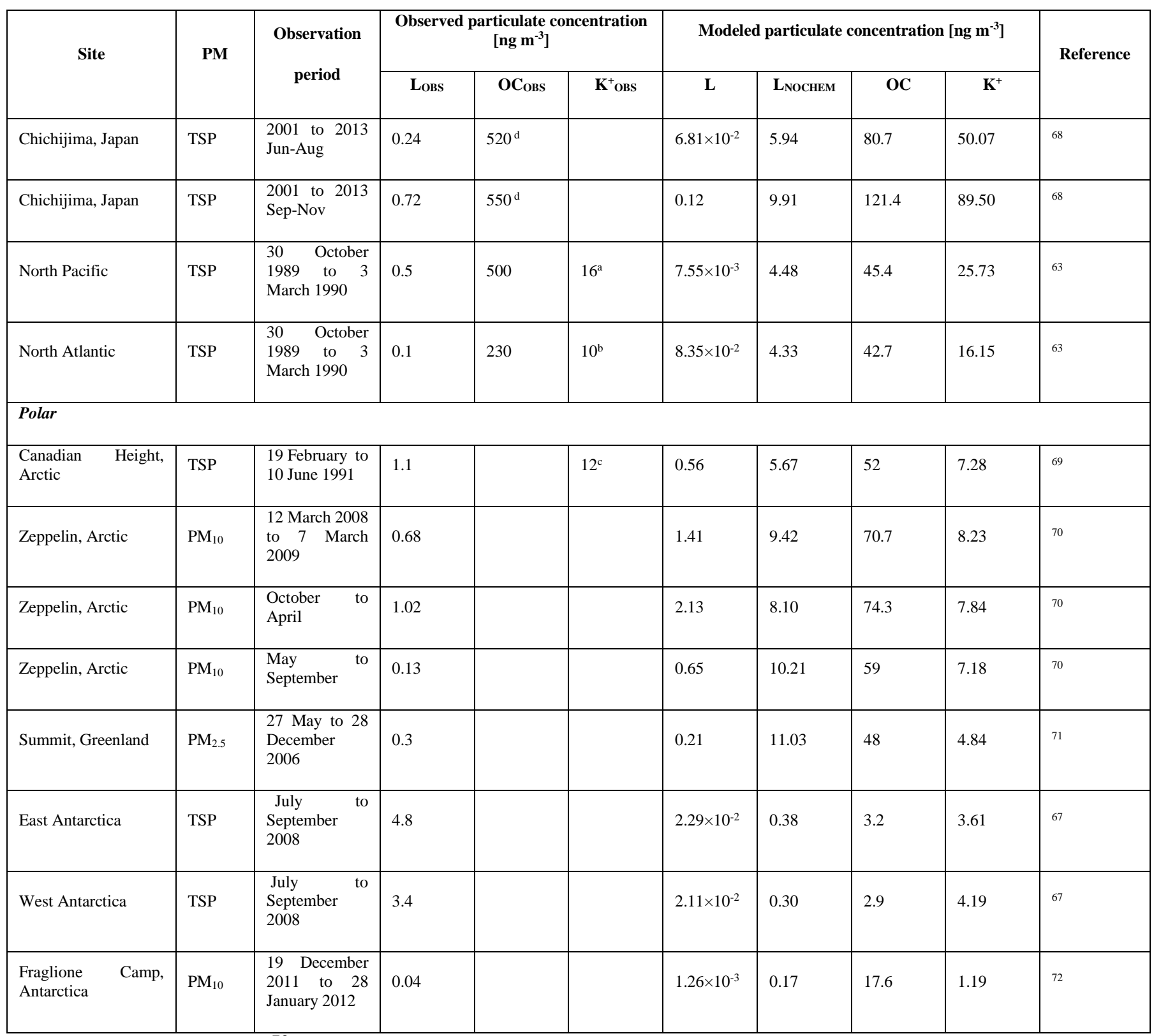

133 a From Matsumoto et al. ${ }^{73}$

$134{ }^{\mathrm{b}}$ From Hoffman et al. ${ }^{74}$

$135{ }^{\mathrm{c}}$ From Li and Winchester ${ }^{75}$

$136{ }^{\mathrm{d}}$ From Mochida et al. ${ }^{76}$ 
With atmospheric degradation (gas phase levoglucosan)
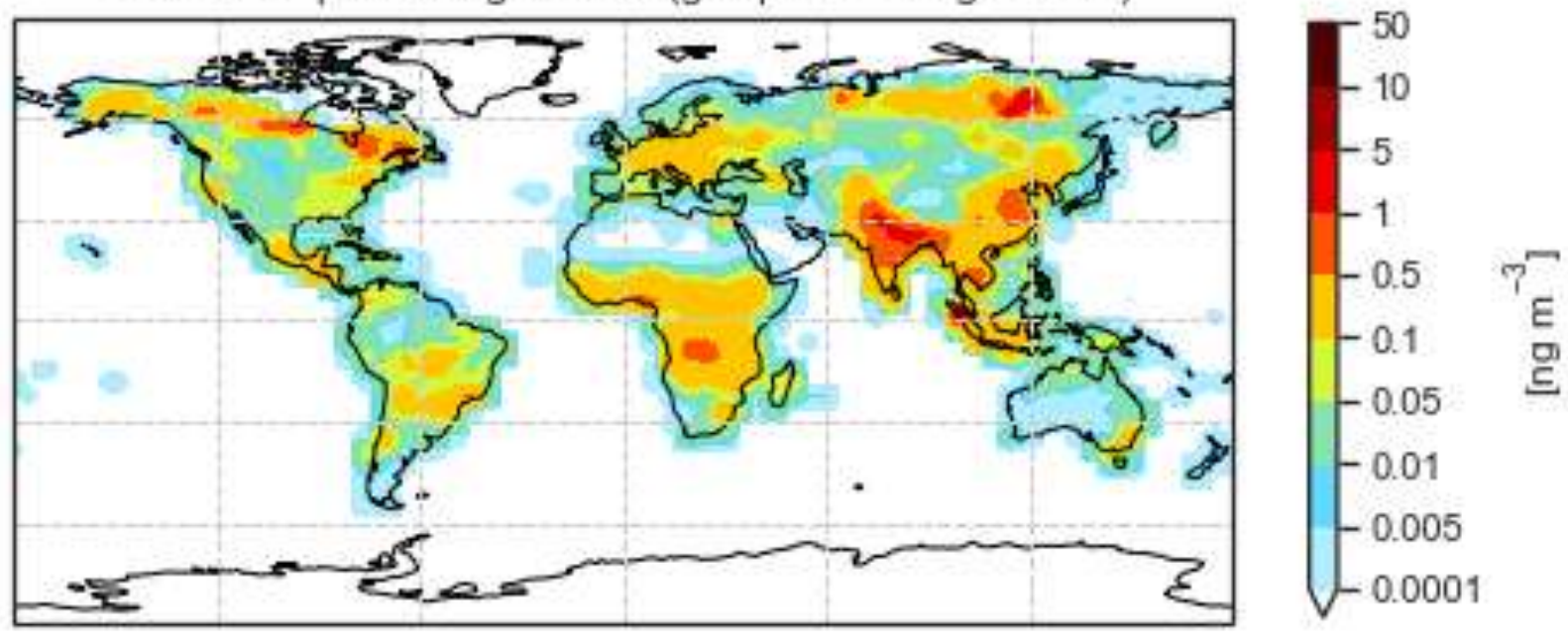

139

140 Figure S1. Simulated gas-phase levoglucosan concentration with atmospheric degradation 141 


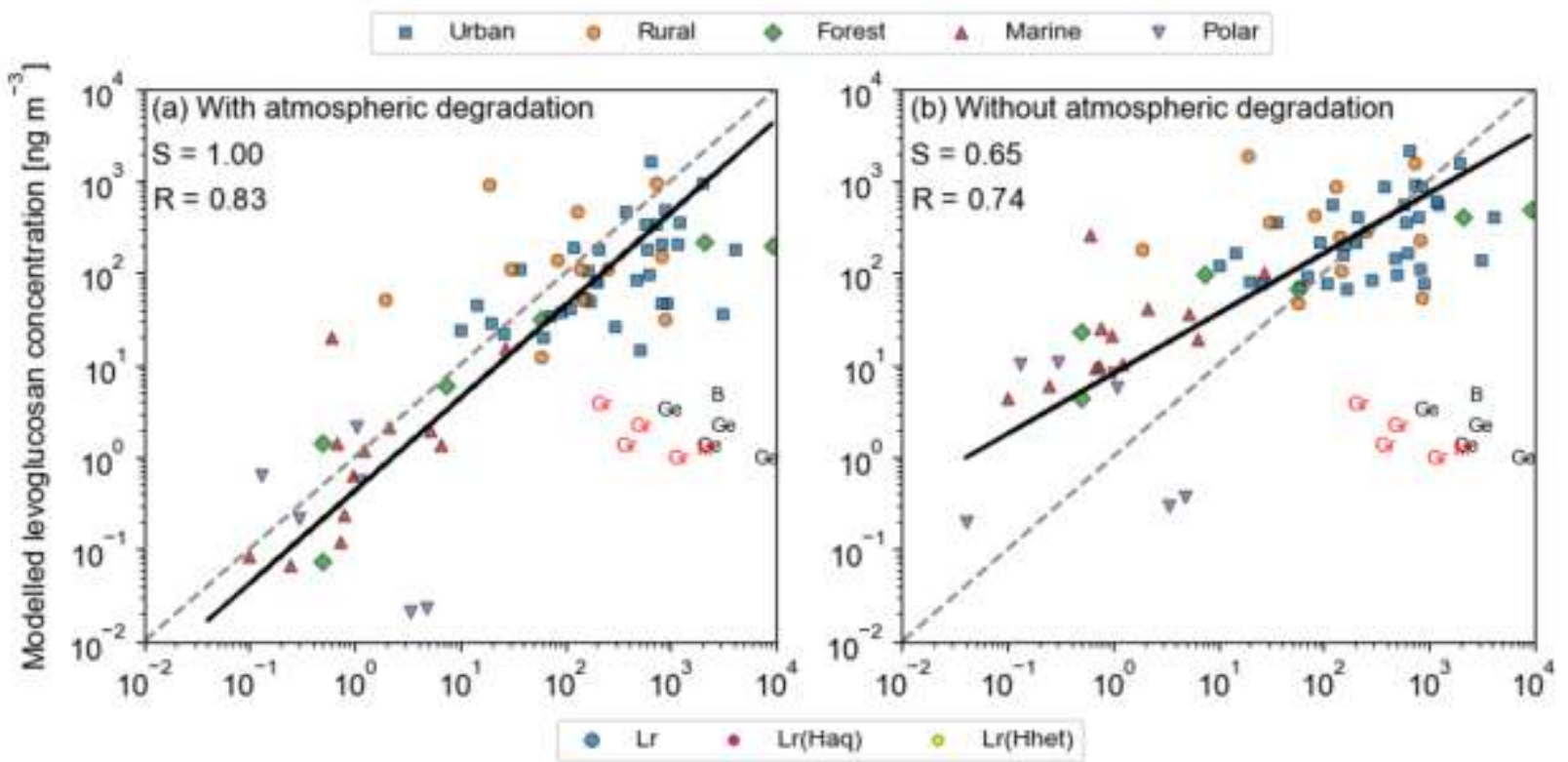

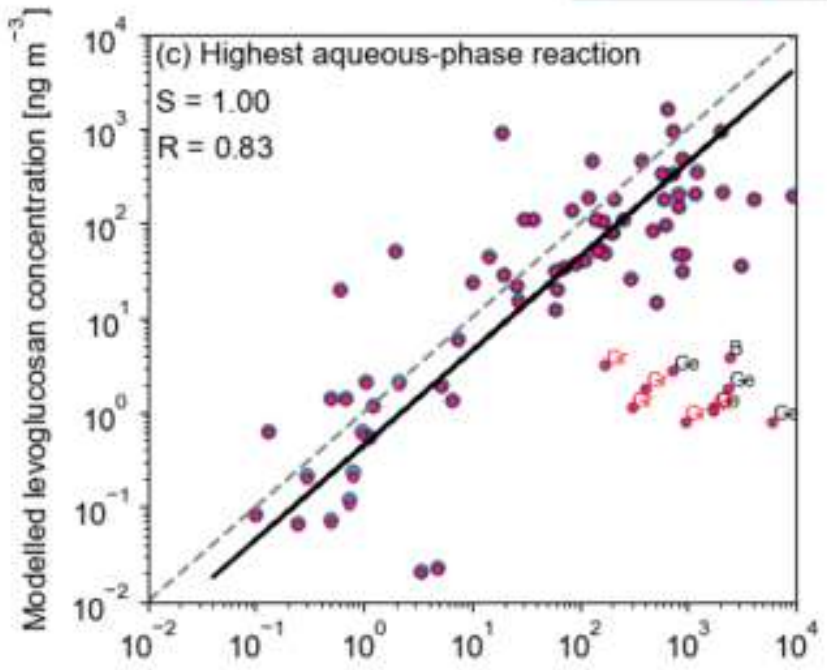

Observed levoglucosan concentration [ng $\mathrm{m}^{-3}$ ]

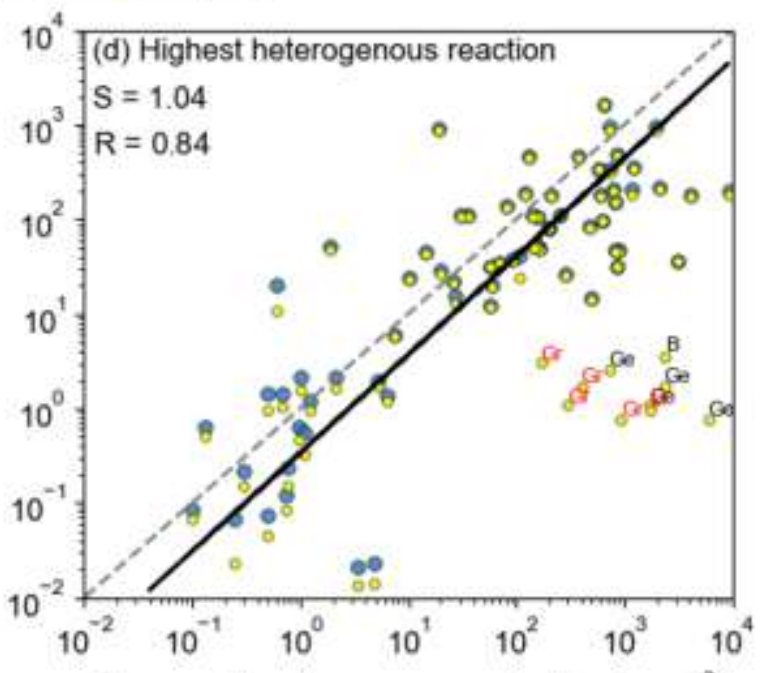

Observed levoglucosan concentration [ng $\mathrm{m}^{-3}$ ]

143 Figure S2. Scatter plots of the observed and simulated particulate levoglucosan concentrations (a)

144 when atmospheric degradation of levoglucosan was taken into account in the model and (b) when

145 it was not. Also shown are sensitivity simulation results (c) when we adopt a high-end aqueous-

146 phase oxidation rates $\left(r_{\mathrm{OH}}(\mathrm{T})=[\mathrm{L}]_{\mathrm{aq}} \cdot[\mathrm{OH}]_{\mathrm{aq}} \cdot 9.1 \times 10^{10} \exp \left(\frac{-1083}{T}\right)\right)$, and $\quad r_{\mathrm{NO}_{3}}(\mathrm{~T})=$

$\left.147[\mathrm{~L}]_{\mathrm{aq}} \cdot\left[\mathrm{NO}_{3}\right]_{\mathrm{aq}} \cdot 2.4 \times 10^{10} \exp \left(\frac{-2141}{T}\right)\right)($ red circles) and $(\mathrm{d})$ when we adopt high-end values for the

148 heteorogenous update of oxidants $\left(\gamma_{\mathrm{OH}}=27, \gamma_{\mathrm{O} 3}=2.5 \times 10^{-5}, \gamma_{\mathrm{NO} 3}=2.3 \times 10^{-3}, \gamma_{\mathrm{N} 2 \mathrm{O} 5}=6.4 \times 10^{-5}\right)$ 
149 (yellow diamonds). The observation data are listed in Table S1 and are coded here by their site 150 types: urban (square), rural (circle), forest (diamond), marine (triangle), and polar (inverted 151 triantle). The letters 'B', 'Ge', 'Gr', and ' $\mathrm{M}$ ' marked outliers measured at Bakersfield (USA), 152 Geeveston (Australia), Grove (Australia), and Manjimup (Australia). Measurements at these sites 153 were excluded in the reduced major axis regression (black lines, calculated on the log-scale). For 154 (c) and (d), the blue symbols and the letters represent observation/simulation comparison for the 155 standard simulation with atmospheric degradation (i.e., (a)). The slopes (S, on the log-scale) of the 156 regression and the correlation coefficients $(\mathrm{R})$ are shown inset. The grey dashed lines indicate the $157 \quad 1: 1$ lines. 
(a) Differences between $\mathrm{L}$ and $\mathrm{L}_{\text {NOCHEM }}$

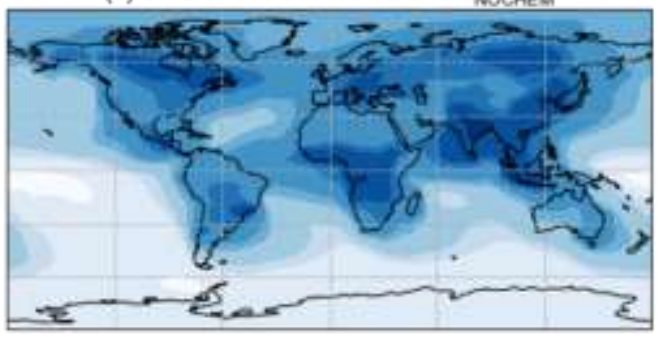

(c) $\mathrm{LL}_{\text {NOCHEM }}$ in January

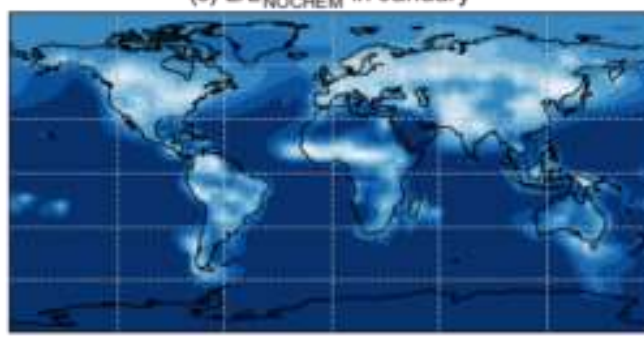

(b) Annual mean $\mathrm{L} \mathrm{L}_{\text {NOCHEM }}$
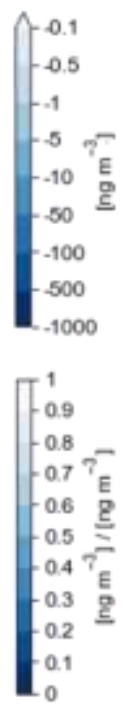

(d) $\mathrm{L} / \mathrm{L}_{\text {NOCHEM }}$ in July
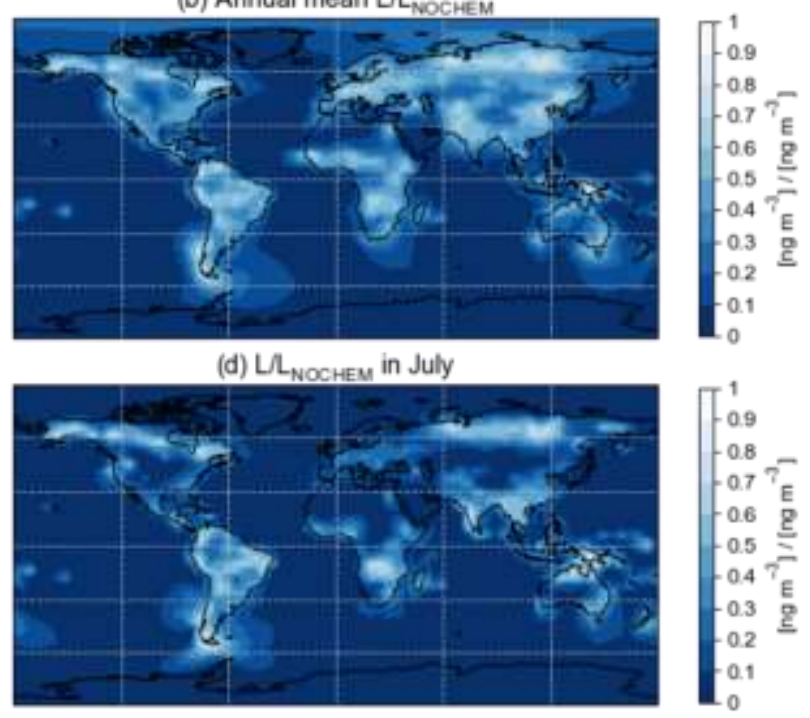

Figure S3. (a) Difference between simulated particulate levoglucosan concentrations with ([L])

161 and without ([L $\left.\mathrm{L}_{\mathrm{NOCHEM}}\right]$ ) atmospheric degradation, and the simulated global distribution

$162[\mathrm{~L}] /\left[\mathrm{L}_{\text {NOCHEM }}\right]$ (b) as an annual mean, (c) in January, and (d) in July. 

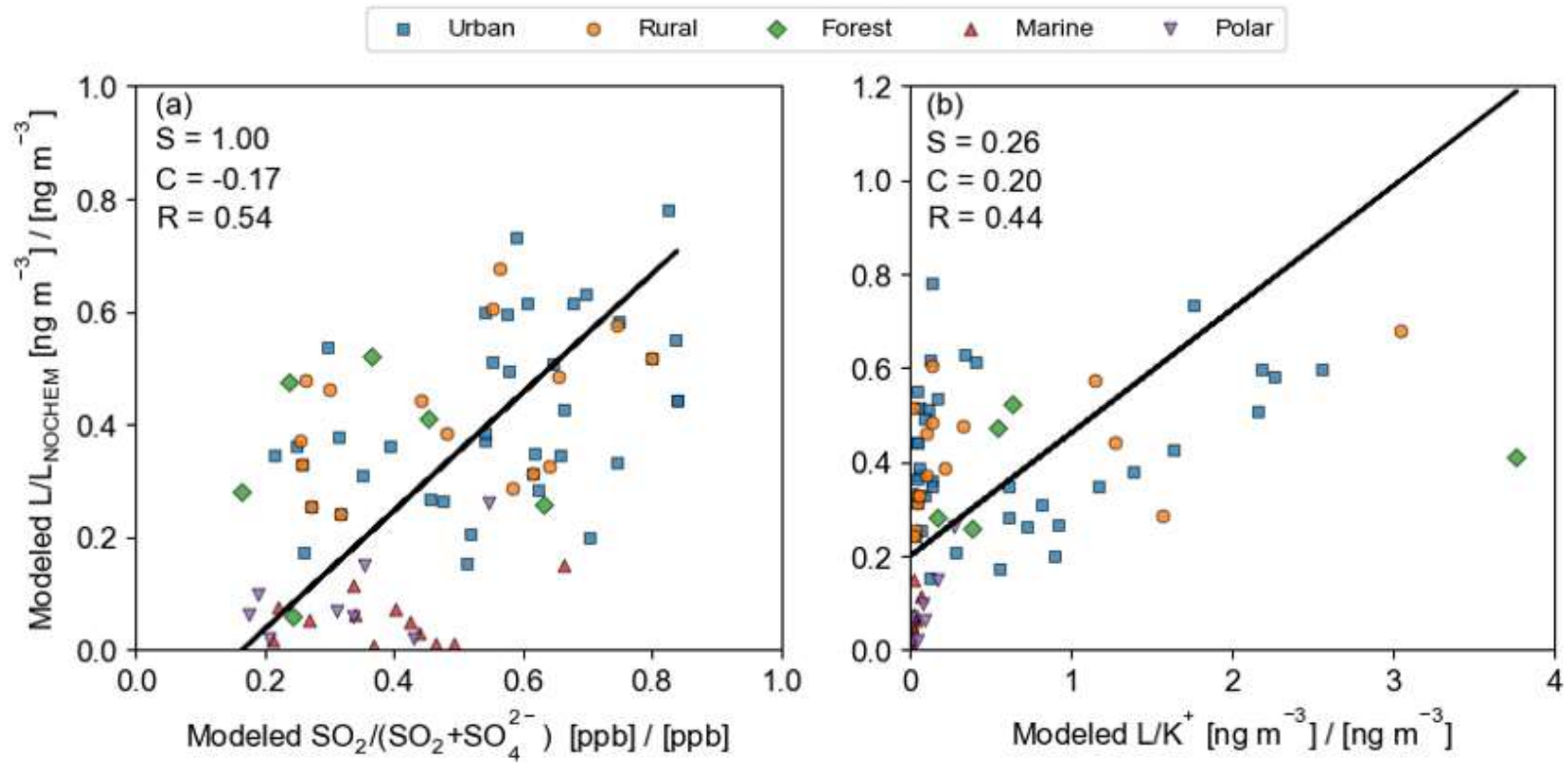

Figure S4. Scatterplots of (a) the simulated $[\mathrm{L}] /\left[\mathrm{L}_{\text {NOCHEM }}\right]$ ratio $(\equiv x)$ versus the simulated

$166\left[\mathrm{SO}_{2}\right] /\left(\left[\mathrm{SO}_{2}\right]+\left[\mathrm{SO}_{4}{ }^{2-}\right]\right)$ ratio, and (b) the simulated $[\mathrm{L}] /\left[\mathrm{L}_{\mathrm{NOCHEM}}\right]$ ratio versus the simulated

$167[\mathrm{~L}] /\left[\mathrm{K}^{+}\right]$ratio, where $\left[\mathrm{K}^{+}\right]$is the concentration of total $\mathrm{K}^{+}$. The black lines show the reduce major 168 axis linear regression lines; the slopes $(\mathrm{S})$, intercepts $(\mathrm{C})$, and correlation coefficients $(\mathrm{R})$ are 169 shown inset. 


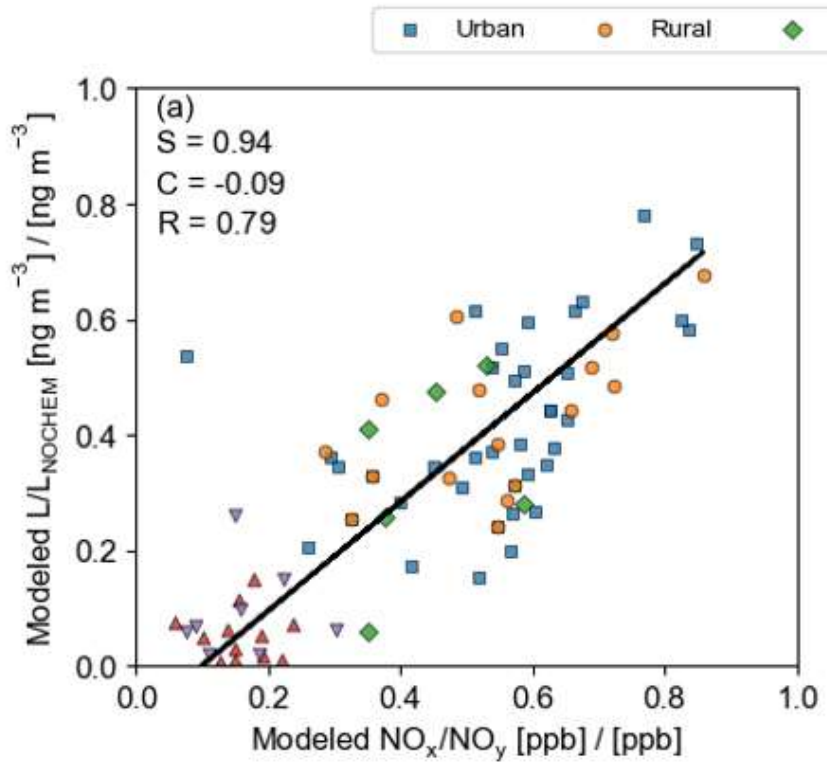

171

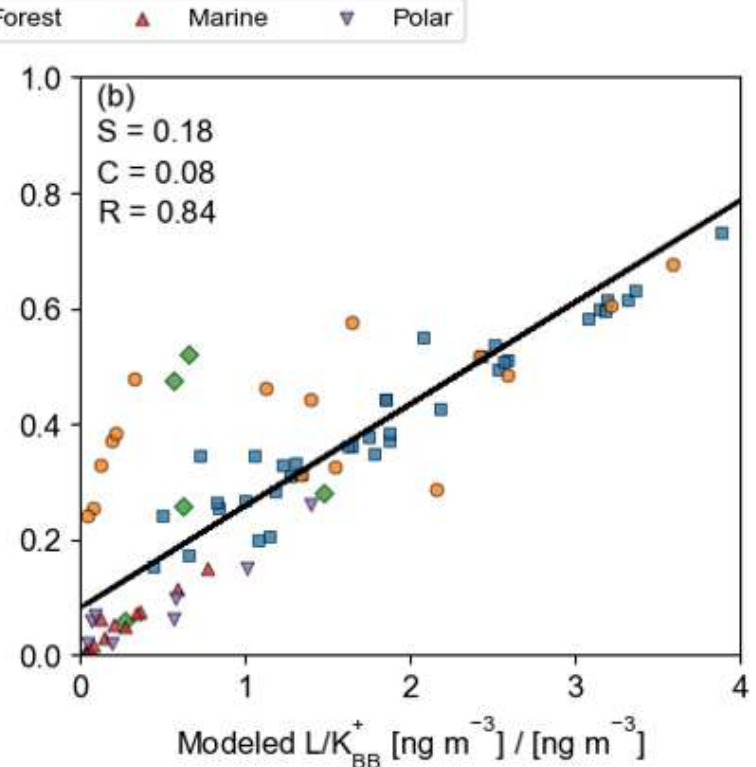

172 Figure S5. Scatterplots of the simulated $[\mathrm{L}] /\left[\mathrm{L}_{\mathrm{NOCHEM}}\right]$ ratio $(\equiv x)$ (a) versus the simulated

$173\left[\mathrm{NO}_{\mathrm{x}}\right] /\left[\mathrm{NO}_{\mathrm{y}}\right]$ ratio and $(\mathrm{b})$ versus the simulated $[\mathrm{L}] /\left[\mathrm{K}^{+}{ }_{\mathrm{BB}}\right]$ ratio, where $\left[\mathrm{K}^{+}{ }_{\mathrm{BB}}\right]$ is the concentration

174 of $\mathrm{K}^{+}$emitted from biomass burning. The black lines show the reduced major axis linear regression

175 lines; the slopes (S), intercepts (C), and correlation coefficients (R) are shown inset. 


\section{Reference}

1. Park, R. J.; Jacob, D. J.; Field, B. D.; Yantosca, R. M.; Chin, M., Natural and transboundary pollution influences on sulfate-nitrate-ammonium aerosols in the United States: Implications for policy. Journal of Geophysical ResearchAtmospheres 2004, 109, (D15), D15204.

2. Parrella, J. P.; Jacob, D. J.; Liang, Q.; Zhang, Y.; Mickley, L. J.; Miller, B.; Evans, M. J.; Yang, X.; Pyle, J. A.; Theys, N.; Van Roozendael, M., Tropospheric bromine chemistry: implications for present and pre-industrial ozone and mercury. Atmospheric Chemistry and Physics 2012, 12, (15), 6723-6740.

3. Mao, J. Q.; Paulot, F.; Jacob, D. J.; Cohen, R. C.; Crounse, J. D.; Wennberg, P. O.; Keller, C. A.; Hudman, R. C.; Barkley, M. P.; Horowitz, L. W., Ozone and organic nitrates over the eastern United States: Sensitivity to isoprene chemistry. Journal of Geophysical Research-Atmospheres 2013, 118, (19), 11256-11268.

4. Park, R. J.; Jacob, D. J.; Chin, M.; Martin, R. V., Sources of carbonaceous aerosols over the United States and implications for natural visibility. Journal of Geophysical Research-Atmospheres 2003, 108, (D12), 4355.

5. Fairlie, T. D.; Jacob, D. J.; Park, R. J., The impact of transpacific transport of mineral dust in the United States. Atmospheric Environment 2007, 41, (6), 1251-1266.

6. Jaeglé, L.; Quinn, P. K.; Bates, T. S.; Alexander, B.; Lin, J. T., Global distribution of sea salt aerosols: new constraints from in situ and remote sensing observations. Atmospheric Chemistry and Physics 2011, 11, (7), 31373157.

7. Pai, S. J.; Heald, C. L.; Pierce, J. R.; Farina, S. C.; Marais, E. A.; Jimenez, J. L.; Campuzano-Jost, P.; Nault, B. A.; Middlebrook, A. M.; Coe, H.; Shilling, J. E.; Bahreini, R.; Dingle, J. H.; Vu, K., An evaluation of global organic aerosol schemes using airborne observations. Atmospheric Chemistry and Physics 2020, 20, (5), 2637-2665.

8. Fountoukis, C.; Nenes, A., ISORROPIA II: a computationally efficient thermodynamic equilibrium model for K+$\mathrm{Ca} 2+-\mathrm{Mg} 2+-\mathrm{Nh}(4)(+)-\mathrm{Na}+-\mathrm{SO} 42--\mathrm{NO} 3--\mathrm{Cl}--\mathrm{H} 2 \mathrm{O}$ aerosols. Atmospheric Chemistry and Physics 2007, 7, (17), 46394659.

9. Pye, H. O. T.; Liao, H.; Wu, S.; Mickley, L. J.; Jacob, D. J.; Henze, D. K.; Seinfeld, J. H., Effect of changes in climate and emissions on future sulfate-nitrate-ammonium aerosol levels in the United States. Journal of Geophysical Research-Atmospheres 2009, 114, D01205.

10. Philip, S.; Martin, R. V.; Pierce, J. R.; Jimenez, J. L.; Zhang, Q.; Canagaratna, M. R.; Spracklen, D. V.; Nowlan, C. R.; Lamsal, L. N.; Cooper, M. J.; Krotkov, N. A., Spatially and seasonally resolved estimate of the ratio of organic mass to organic carbon. Atmospheric Environment 2014, 87, 34-40.

11. Lin, S. J.; Rood, R. B., Multidimensional flux-form semi-Lagrangian transport schemes. Monthly Weather Review 1996, 124, (9), 2046-2070.

12. Wesely, M. L., Parameterization of surface resistances to gaseous dry deposition in regional-scale numerical models. Atmospheric Environment 1989, 23, (6), 1293-1304.

13. Zhang, L. M.; Gong, S. L.; Padro, J.; Barrie, L., A size-segregated particle dry deposition scheme for an atmospheric aerosol module. Atmospheric Environment 2001, 35, (3), 549-560.

14. Liu, H. Y.; Jacob, D. J.; Bey, I.; Yantosca, R. M., Constraints from Pb-210 and Be-7 on wet deposition and transport in a global three-dimensional chemical tracer model driven by assimilated meteorological fields. Journal of Geophysical Research-Atmospheres 2001, 106, (D11), 12109-12128.

15. Amos, H. M.; Jacob, D. J.; Holmes, C. D.; Fisher, J. A.; Wang, Q.; Yantosca, R. M.; Corbitt, E. S.; Galarneau, E.; Rutter, A. P.; Gustin, M. S.; Steffen, A.; Schauer, J. J.; Graydon, J. A.; St Louis, V. L.; Talbot, R. W.; Edgerton, E. S.; 
Zhang, Y.; Sunderland, E. M., Gas-particle partitioning of atmospheric $\mathrm{Hg}(\mathrm{II})$ and its effect on global mercury deposition. Atmospheric Chemistry and Physics 2012, 12, (1), 591-603.

16. Hoesly, R. M.; Smith, S. J.; Feng, L. Y.; Klimont, Z.; Janssens-Maenhout, G.; Pitkanen, T.; Seibert, J. J.; Vu, L.; Andres, R. J.; Bolt, R. M.; Bond, T. C.; Dawidowski, L.; Kholod, N.; Kurokawa, J.; Li, M.; Liu, L.; Lu, Z. F.; Moura, M. C. P.; O'Rourke, P. R.; Zhang, Q., Historical (1750-2014) anthropogenic emissions of reactive gases and aerosols from the Community Emissions Data System (CEDS). Geoscientific Model Development 2018, 11, (1), 369-408.

17. Li, M.; Zhang, Q.; Kurokawa, J.; Woo, J. H.; He, K. B.; Lu, Z. F.; Ohara, T.; Song, Y.; Streets, D. G.; Carmichael, G. R.; Cheng, Y. F.; Hong, C. P.; Huo, H.; Jiang, X. J.; Kang, S. C.; Liu, F.; Su, H.; Zheng, B., MIX: a mosaic Asian anthropogenic emission inventory under the international collaboration framework of the MICS-Asia and HTAP. Atmospheric Chemistry and Physics 2017, 17, (2), 935-963.

18. Marais, E. A.; Wiedinmyer, C., Air quality impact of diffuse and inefficient combustion emissions in Africa (DICEAfrica). Environmental Science \& Technology 2016, 50, (19), 10739-10745.

19. van der Werf, G. R.; Randerson, J. T.; Giglio, L.; van Leeuwen, T. T.; Chen, Y.; Rogers, B. M.; Mu, M. Q.; van Marle, M. J. E.; Morton, D. C.; Collatz, G. J.; Yokelson, R. J.; Kasibhatla, P. S., Global fire emissions estimates during 19972016. Earth System Science Data 2017, 9, (2), 697-720.

20. Guenther, A. B.; Jiang, X.; Heald, C. L.; Sakulyanontvittaya, T.; Duhl, T.; Emmons, L. K.; Wang, X., The model of rmissions of gases and aerosols from Nature version 2.1 (MEGAN2.1): an extended and updated framework for modeling biogenic emissions. Geoscientific Model Development 2012, 5, (6), 1471-1492.

21. Hoffmann, D.; Tilgner, A.; linuma, Y.; Herrmann, H., Atmospheric stability of levoglucosan: a detailed laboratory 236 and modeling study. Environmental Science \& Technology 2010, 44, (2), 694-699.

22. Kessler, S. H.; Smith, J. D.; Che, D. L.; Worsnop, D. R.; Wilson, K. R.; Kroll, J. H., Chemical sinks of organic aerosol: kinetics and products of the heterogeneous oxidation of erythritol and levoglucosan. Environmental Science \& Technology 2010, 44, (18), 7005-7010.

23. Slade, J. H.; Knopf, D. A., Heterogeneous $\mathrm{OH}$ oxidation of biomass burning organic aerosol surrogate compounds: assessment of volatilisation products and the role of $\mathrm{OH}$ concentration on the reactive uptake kinetics. Physical Chemistry Chemical Physics 2013, 15, (16), 5898-5915.

24. Slade, J. H.; Knopf, D. A., Multiphase $\mathrm{OH}$ oxidation kinetics of organic aerosol: The role of particle phase state and relative humidity. Geophysical Research Letters 2014, 41, (14), 5297-5306.

245 25. Arangio, A. M.; Slade, J. H.; Berkemeier, T.; Poschl, U.; Knopf, D. A.; Shiraiwa, M., Multiphase chemical kinetics of $\mathrm{OH}$ radical uptake by molecular organic markers of biomass burning aerosols: humidity and temperature dependence, surface reaction, and bulk diffusion. Journal of Physical Chemistry A 2015, 119, (19), 4533-4544.

26. Lai, C. Y.; Liu, Y. C.; Ma, J. Z.; Ma, Q. X.; He, H., Degradation kinetics of levoglucosan initiated by hydroxyl radical under different environmental conditions. Atmospheric Environment 2014, 91, 32-39.

250 27. Knopf, D. A.; Forrester, S. M.; Slade, J. H., Heterogeneous oxidation kinetics of organic biomass burning aerosol 251 surrogates by O-3, NO2, N2O5, and NO3. Physical Chemistry Chemical Physics 2011, 13, (47), 21050-21062. 
29. Giri, B.; Patel, K. S.; Jaiswal, N. K.; Sharma, S.; Ambade, B.; Wang, W. T.; Simonich, S. L. M.; Simoneit, B. R. T., Composition and sources of organic tracers in aerosol particles of industrial central India. Atmospheric Research 2013, 120, 312-324.

30. Wang, G. H.; Chen, C. L.; Li, J. J.; Zhou, B. H.; Xie, M. J.; Hu, S. Y.; Kawamura, K.; Chen, Y., Molecular composition and size distribution of sugars, sugar-alcohols and carboxylic acids in airborne particles during a severe urban haze event caused by wheat straw burning. Atmospheric Environment 2011, 45, (15), 2473-2479.

31. Liu, X. Y.; Zhang, Y. L.; Peng, Y. R.; Xu, L. L.; Zhu, C. M.; Cao, F.; Zhai, X. Y.; Haque, M. M.; Yang, C.; Chang, Y. H.; Huang, T.; Xu, Z. F.; Bao, M. Y.; Zhang, W. Q.; Fan, M. Y.; Lee, X. H., Chemical and optical properties of carbonaceous aerosols in Nanjing, eastern China: regionally transported biomass burning contribution. Atmospheric Chemistry and Physics 2019, 19, (17), 11213-11233.

32. Shen, Z. X.; Zhang, Q.; Cao, J. J.; Zhang, L. M.; Lei, Y. L.; Huang, Y.; Huang, R. J.; Gao, J. J.; Zhao, Z. Z.; Zhu, C. S.; Yin, X. L.; Zheng, C. L.; Xu, H. M.; Liu, S. X., Optical properties and possible sources of brown carbon in PM2.5 over Xi'an, China. Atmospheric Environment 2017, 150, 322-330.

33. Saarikoski, S.; Sillanpaa, M.; Sofiev, M.; Timonen, H.; Saarnio, K.; Teinela, K.; Karppinen, A.; Kukkonen, J.; Hillamo, R., Chemical composition of aerosols during a major biomass burning episode over northern Europe in spring 2006: Experimental and modelling assessments. Atmospheric Environment 2007, 41, (17), 3577-3589.

34. Zdrahal, Z.; Oliveira, J.; Vermeylen, R.; Claeys, M.; Maenhaut, W., Improved method for quantifying levoglucosan and related monosaccharide anhydrides in atmospheric aerosols and application to samples from urban and tropical locations. Environmental Science \& Technology 2002, 36, (4), 747-753.

35. Nolte, C. G.; Schauer, J. J.; Cass, G. R.; Simoneit, B. R. T., Highly polar organic compounds present in wood smoke and in the ambient atmosphere. Environmental Science \& Technology 2001, 35, (10), 1912-1919.

36. Reisen, F.; Meyer, C. P.; Keywood, M. D., Impact of biomass burning sources on seasonal aerosol air quality. Atmospheric Environment 2013, 67, 437-447.

37. Cheng, Y.; Engling, G.; He, K. B.; Duan, F. K.; Ma, Y. L.; Du, Z. Y.; Liu, J. M.; Zheng, M.; Weber, R. J., Biomass burning contribution to Beijing aerosol. Atmospheric Chemistry and Physics 2013, 13, (15), 7765-7781.

38. Szidat, S.; Jenk, T. M.; Synal, H. A.; Kalberer, M.; Wacker, L.; Hajdas, I.; Kasper-Giebl, A.; Baltensperger, U., Contributions of fossil fuel, biomass-burning, and biogenic emissions to carbonaceous aerosols in Zurich as traced by C-14. Journal of Geophysical Research-Atmospheres 2006, 111, (D7), D07206.

39. Hedberg, E.; Johansson, C., Is levoglucosan a suitable quantitative tracer for wood burning? Comparison with receptor modeling on trace elements in Lycksele, Sweden. Journal of the Air \& Waste Management Association 2006, 56, (12), 1669-1678.

40. Yttri, K. E.; Dye, C.; Slordal, L. H.; Braathen, O. A., Quantification of monosaccharide anhydrides by liquid chromatography combined with mass spectrometry: Application to aerosol samples from an urban and a suburban site influenced by small-scale wood burning. Journal of the Air \& Waste Management Association 2005, 55, (8), 11691177.

41. Reche, C.; Viana, M.; Amato, F.; Alastuey, A.; Moreno, T.; Hillamo, R.; Teinila, K.; Saarnio, K.; Seco, R.; Penuelas, J.; Mohr, C.; Prevot, A. S. H.; Querol, X., Biomass burning contributions to urban aerosols in a coastal Mediterranean City. Science of the Total Environment 2012, 427, 175-190.

42. Fraser, M. P.; Lakshmanan, K., Using levoglucosan as a molecular marker for the long-range transport of biomass combustion aerosols. Environmental Science \& Technology 2000, 34, (21), 4560-4564. 
43. Leithead, A.; Li, S. M.; Hoff, R.; Cheng, Y.; Brook, J., Levoglucosan and dehydroabietic acid: Evidence of biomass burning impact on aerosols in the Lower Fraser Valley. Atmospheric Environment 2006, 40, (15), 2721-2734.

44. Caseiro, A.; Bauer, H.; Schmidl, C.; Pio, C. A.; Puxbaum, H., Wood burning impact on PM10 in three Austrian regions. Atmospheric Environment 2009, 43, (13), 2186-2195.

45. Tsai, Y. I.; Sopajaree, K.; Chotruksa, A.; Wu, H. C.; Kuo, S. C., Source indicators of biomass burning associated with inorganic salts and carboxylates in dry season ambient aerosol in Chiang Mai Basin, Thailand. Atmospheric Environment 2013, 78, 93-104.

46. Yang, L. M.; Nguyen, D. M.; Jia, S. G.; Reid, J. S.; Yu, L. Y. E., Impacts of biomass burning smoke on the distributions and concentrations of C-2-C-5 dicarboxylic acids and dicarboxylates in a tropical urban environment. Atmospheric Environment 2013, 78, 211-218.

47. Polidori, A.; Turpin, B. J.; Lim, H. J.; Cabada, J. C.; Subramanian, R.; Pandis, S. N.; Robinson, A. L., Local and regional secondary organic aerosol: Insights from a year of semi-continuous carbon measurements at Pittsburgh. Aerosol Science and Technology 2006, 40, (10), 861-872.

48. Favez, O.; El Haddad, I.; Piot, C.; Boreave, A.; Abidi, E.; Marchand, N.; Jaffrezo, J. L.; Besombes, J. L.; Personnaz, M. B.; Sciare, J.; Wortham, H.; George, C.; D'Anna, B., Inter-comparison of source apportionment models for the estimation of wood burning aerosols during wintertime in an Alpine city (Grenoble, France). Atmospheric Chemistry and Physics 2010, 10, (12), 5295-5314.

49. Stone, E. A.; Snyder, D. C.; Sheesley, R. J.; Sullivan, A. P.; Weber, R. J.; Schauer, J. J., Source apportionment of fine organic aerosol in Mexico City during the MILAGRO experiment 2006. Atmospheric Chemistry and Physics 2008, 8, (5), 1249-1259.

50. Diapouli, E.; Popovicheva, O.; Kistler, M.; Vratolis, S.; Persiantseva, N.; Timofeev, M.; Kasper-Giebl, A.; Eleftheriadis, K., Physicochemical characterization of aged biomass burning aerosol after long-range transport to Greece from large scale wildfires in Russia and surrounding regions, Summer 2010. Atmospheric Environment 2014, 96, 393-404.

51. Shahid, I.; Kistler, M.; Mukhtar, A.; Ghauri, B. M.; Cruz, C. R. S.; Bauer, H.; Puxbaum, H., Chemical characterization and mass closure of PM10 and PM2.5 at an urban site in Karachi - Pakistan. Atmospheric Environment 2016, 128, 114-123.

52. Sang, X. F.; Chan, C. Y.; Engling, G.; Chan, L. Y.; Wang, X. M.; Zhang, Y. N.; Shi, S.; Zhang, Z. S.; Zhang, T.; Hu, M., Levoglucosan enhancement in ambient aerosol during springtime transport events of biomass burning smoke to Southeast China. Tellus Series B-Chemical and Physical Meteorology 2011, 63, (1), 129-139.

53. Bari, M. A.; Baumbach, G.; Kuch, B.; Scheffknecht, G., Temporal variation and impact of wood smoke pollution on a residential area in southern Germany. Atmospheric Environment 2010, 44, (31), 3823-3832.

54. Ho, K. F.; Engling, G.; Ho, S. S. H.; Huang, R. J.; Lai, S. C.; Cao, J. J.; Lee, S. C., Seasonal variations of anhydrosugars in PM2.5 in the Pearl River Delta Region, China. Tellus Series B-Chemical and Physical Meteorology 2014, 66, 22577.

55. Liang, L. L.; Engling, G.; Cheng, Y.; Liu, X. Y.; Du, Z. Y.; Ma, Q. L.; Zhang, X. Y.; Sun, J. Y.; Xu, W. Y.; Liu, C.; Zhang, G.; Xu, H., Biomass burning impacts on ambient aerosol at a background site in East China: Insights from a yearlong study. Atmospheric Research 2020, 231, UNSP 104660.

56. Wan, X.; Kang, S. C.; Li, Q. L.; Rupakheti, D.; Zhang, Q. G.; Guo, J. M.; Chen, P. F.; Tripathee, L.; Rupakheti, M.; Panday, A. K.; Wang, W.; Kawamura, K.; Gao, S. P.; Wu, G. M.; Cong, Z. Y., Organic molecular tracers in the atmospheric aerosols from Lumbini, Nepal, in the northern Indo-Gangetic Plain: influence of biomass burning.

336 Atmospheric Chemistry and Physics 2017, 17, (14), 8867-8885. 
57. Mkoma, S. L.; Kawamura, K.; Fu, P. Q., Contributions of biomass/biofuel burning to organic aerosols and particulate matter in Tanzania, East Africa, based on analyses of ionic species, organic and elemental carbon, levoglucosan and mannosan. Atmospheric Chemistry and Physics 2013, 13, (20), 10325-10338.

58. Reisen, F.; Meyer, C. P.; McCaw, L.; Powell, J. C.; Tolhurst, K.; Keywood, M. D.; Gras, J. L., Impact of smoke from biomass burning on air quality in rural communities in southern Australia. Atmospheric Environment 2011, 45, (24), 3944-3953.

59. Urban, R. C.; Lima-Souza, M.; Caetano-Silva, L.; Queiroz, M. E. C.; Nogueira, R. F. P.; Allen, A. G.; Cardoso, A. A.; Held, G.; Campos, M., Use of levoglucosan, potassium, and water-soluble organic carbon to characterize the origins of biomass-burning aerosols. Atmospheric Environment 2012, 61, 562-569.

60. Cong, Z.; Kang, S.; Kawamura, K.; Liu, B.; Wan, X.; Wang, Z.; Gao, S.; Fu, P., Carbonaceous aerosols on the south edge of the Tibetan Plateau: concentrations, seasonality and sources. Atmospheric Chemistry and Physics 2015, 15, (3), 1573-1584.

61. Shen, R. Q.; Ding, X.; He, Q. F.; Cong, Z. Y.; Yu, Q. Q.; Wang, X. M., Seasonal variation of secondary organic aerosol tracers in Central Tibetan Plateau. Atmospheric Chemistry and Physics 2015, 15, (15), 8781-8793.

62. Pio, C. A.; Legrand, M.; Alves, C. A.; Oliveira, T.; Afonso, J.; Caseiro, A.; Puxbaum, H.; Sanchez-Ochoa, A.; Gelencser, A., Chemical composition of atmospheric aerosols during the 2003 summer intense forest fire period. Atmospheric Environment 2008, 42, (32), 7530-7543.

63. Fu, P. Q.; Kawamura, K.; Miura, K., Molecular characterization of marine organic aerosols collected during a round-the-world cruise. Journal of Geophysical Research-Atmospheres 2011, 116, D13302.

64. Claeys, M.; Kourtchev, I.; Pashynska, V.; Vas, G.; Vermeylen, R.; Wang, W.; Cafmeyer, J.; Chi, X.; Artaxo, P.; Andreae, M. O.; Maenhaut, W., Polar organic marker compounds in atmospheric aerosols during the LBA-SMOCC 2002 biomass burning experiment in Rondonia, Brazil: sources and source processes, time series, diel variations and size distributions. Atmospheric Chemistry and Physics 2010, 10, (19), 9319-9331.

65. Panov, A. V.; Prokushkin, A. S.; Korets, M. A.; Bryukhanov, A. V.; Myers-Pigg, A. N.; Louchouarn, P.; Sidenko, N. V.; Amon, R.; Andreae, M. O.; Heimann, M. In Linking trace gas measurements and molecular tracers of organic matter in aerosols for identification of ecosystem sources and types of wildfires in Central Siberia, 9th International Multidisciplinary Conference and Early Career Scientists School on Environmental Observations, Modelling and Information Systems (ENVIROMIS), Tomsk, RUSSIA, Jul 11-16, 2016; Tomsk, RUSSIA, 2016.

66. Garcia, M. I.; van Drooge, B. L.; Rodriguez, S.; Alastuey, A., Speciation of organic aerosols in the Saharan Air Layer and in the free troposphere westerlies. Atmospheric Chemistry and Physics 2017, 17, (14), 8939-8958.

67. Hu, Q. H.; Xie, Z. Q.; Wang, X. M.; Kang, H.; Zhang, P. F., Levoglucosan indicates high levels of biomass burning aerosols over oceans from the Arctic to Antarctic. Scientific Reports 2013, 3, 3119.

68. Verma, S. K.; Kawamura, K.; Chen, J.; Fu, P. Q.; Zhu, C. M., Thirteen years of observations on biomass burning organic tracers over Chichijima Island in the western North Pacific: An outflow region of Asian aerosols. Journal of Geophysical Research-Atmospheres 2015, 120, (9), 4155-4168.

69. Fu, P. Q.; Kawamura, K.; Barrie, L. A., Photochemical and Other Sources of Organic Compounds in the Canadian High Arctic Aerosol Pollution during Winter-Spring. Environmental Science \& Technology 2009, 43, (2), $286-292$.

70. Yttri, K. E.; Myhre, C. L.; Eckhardt, S.; Fiebig, M.; Dye, C.; Hirdman, D.; Strom, J.; Klimont, Z.; Stohl, A., Quantifying black carbon from biomass burning by means of levoglucosan - a one-year time series at the Arctic observatory Zeppelin. Atmospheric Chemistry and Physics 2014, 14, (12), 6427-6442. 

carbonaceous aerosol in the atmosphere of Summit, Greenland. Atmospheric Environment 2009, 43, (27), 41553794162.

380 72. Zangrando, R.; Barbaro, E.; Vecchiato, M.; Kehrwald, N. M.; Barbante, C.; Gambaro, A., Levoglucosan and 381 phenols in Antarctic marine, coastal and plateau aerosols. Science of the Total Environment 2016, 544, 606-616.

382 73. Matsumoto, K.; Nagao, I.; Tanaka, H.; Miyaji, H.; lida, T.; Ikebe, Y., Seasonal characteristics of organic and 383 inorganic species and their size distributions in atmospheric aerosols over the northwest Pacific Ocean. Atmospheric 384 Environment 1998, 32, (11), 1931-1946.

385 74. Hoffman, E. J.; Hoffman, G. L.; Duce, R. A., Particle size dependence of alkali and alkaline Earth metal enrichment 386 in marine aerosols from Bermuda. Journal of Geophysical Research-Oceans 1980, 85, (NC10), 5499-5502.

387 75. Li, S. M.; Winchester, J. W., Particle size distribution and chemistry of late winter Arctic aerosols. Journal of 388 Geophysical Research-Atmospheres 1990, 95, (D9), 13897-13908.

389 76. Mochida, M.; Kawamura, K.; Fu, P. Q.; Takemura, T., Seasonal variation of levoglucosan in aerosols over the 390 western North Pacific and its assessment as a biomass-burning tracer. Atmospheric Environment 2010, 44, (29), $3913511-3518$. 